SYSTEMATIC REVIEW

\title{
VISCERAL MOBILIZATION AS MANAGEMENT OPTION FOR LOW BACK PAIN - A SYSTEMATIC REVIEW
}

\begin{abstract}
\section{OBJECTIVE}

This systematic review is to evaluate the impact of visceral mobilization or manipulation in improving low back pain via standard protocols.

\section{MATERIALS AND METHODS}

Literature was searched electronically on various databases such as PEDro, PubMed Central, Google Scholar, BioMed Central, MEDLINE, EMBASE and Science Direct considering duration of 2011 to 2019. Randomized Controlled Trials investigating effectiveness of visceral manipulation or mobilization, either, in the comparison with different modalities or with sham/placebo were included. Data was extracted and studies were reviewed on standardized qualitative assessment criteria. Cochrane guidelines were followed to find out the risk of bias among the included studies.
\end{abstract}

\section{RESULTS}

All the studies provided moderate to high quality evidence in favor of visceral mobilization or manipulation being effective on low back pain in terms of risk of bias and quality assessment with significant results ( $p$-value $<0.05$ ).

\section{CONCLUSION}

The available studies provided the significant and strong effectiveness of visceral manipulation and mobilization. However, scarcity of literature in domain raises an inevitable need for further studies to be conducted in future.

\section{KEYWORDS}

Viscera, Mobilization, Low back pain, Quality of life, Sham, Pain.

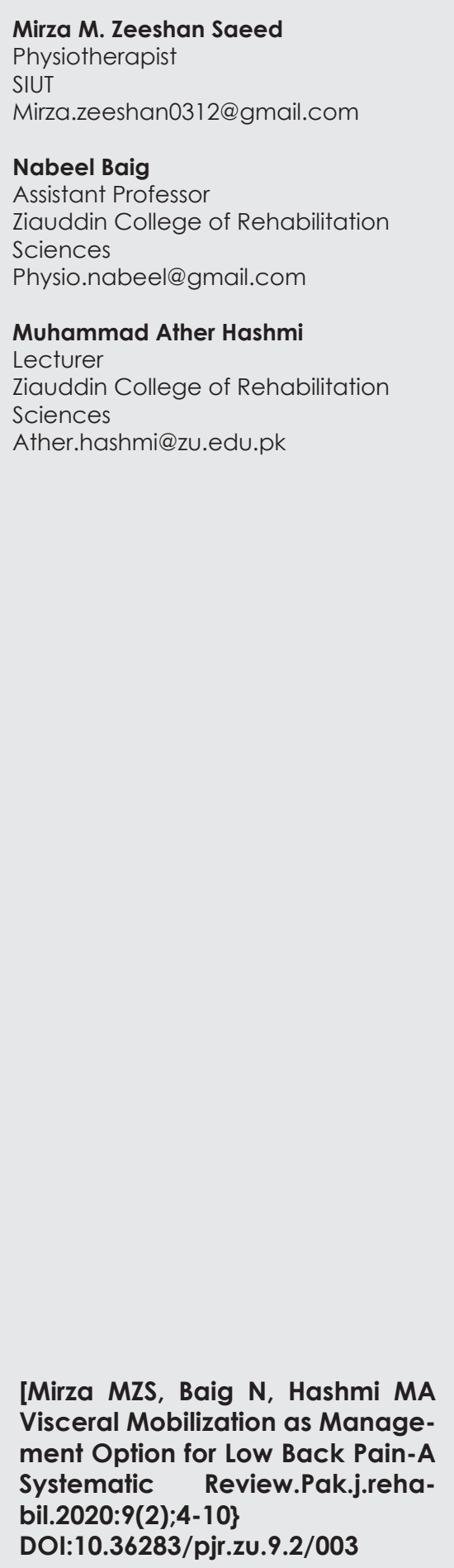




\section{INTRODUCTION}

Low back pain is considered among the most common pathological conditions and it is more associated with comorbidity and disability than any other condition ${ }^{1,2}$. Global prevalence of low back pain is reported $7.5 \%$ at $95 \%$ confidence interval that is higher in females as compared to males ${ }^{3}$. Approximately, about $80 \%$ of the population suffered from low back pain in their life span ${ }^{4}$. Statistical reports of United States suggest that every 1 individual out of 4 adults is reported to have suffered with low back pain almost every day, in last 3 months $^{4}$. However, in most researches, age is regarded as the commonest contributing factor of low back pain ${ }^{5}$. Moreover, it is suggested that the incidence of low back pain increases tremendously, after 60-65 years of age 6 . Furthermore, statistics show that an increased prevalence of low back pain is also related with the patient's educational and socioeconomic statuses ${ }^{7}$. People with low educational status are predicted to suffer more prolonged episodes of low back pain and have a poor prognosis ${ }^{8}$. In other researches low back pain is the termed as an inconvenient condition to be managed for clinicians, patients, and policy makers?. Although, low back pain is equally prevalent among the individuals of all age groups and hinder daily aspects of their life ${ }^{10}$. However, its consequences badly affect the elderly population $^{1}$. Researchers suggest that visceral dysfunction may be the underlying etiology of low back pain or contribute as the aggravating factor for $i^{12}$. There are various approaches prevailed for the management of low back pain, but preliminary evidence demonstrates that visceral mobilization might be effective for the treating low back pain ${ }^{13}$. A recently conducted clinical case series demonstrate that the symptoms of low back pain were improved following a specific visceral manipulation technique in which a mobilization maneuver on the kidneys in people with nonspecific low back pain ${ }^{13}$. Studies show that specific visceral disorders, such as refractory irritable bowel syndrome and chronic constipation in women found good outcomes after visceral techniques on patient with Low back pain ${ }^{14}$. In asymptomatic individuals with chronic Low back pain do not reach the flexion relaxation phenomena, which is decrease in or absence of electromyography activity in paraspinal muscles found at the time of full trunk flexion ${ }^{15}$. The rational for this therapeutic study is that visceral disorders could potentially trigger low back pain ${ }^{14}$. The central sensitization activated by visceral nociceptors, these receptors trigger by alter gut environment/ urinary motility and these visceral receptor evoke peripheral hypersensitivity ${ }^{15}$. This is not yet understood the mechanism of visceral manipulation have effect on pain ${ }^{15}$. Hypothesis reveals, the supportive fascia of the internal cavities of the trunk, visceral nociceptive signaling modulated by visceral manipulation and specific manual treatments ${ }^{14}$. Visceral manipulation has been used for over decade in the treatment of low back pain, but its efficacy remains untested ${ }^{14}$. The mechanism by which visceral pain causes referral to somatic structures could occur by neural convergence, whereby sympathetic afferent nerves that convey signals from the viscera converge with somatic nerves in the dorsal horn ${ }^{14}$. Due to the low proportion of visceral receptors does not induce conscious perception, viscera nociceptive input can be misinterpreted as arising from somatic structures ${ }^{14}$ Evidence shows that people with low back pain has neuromuscular deficit in spine ${ }^{15}$.

\section{METHODOLOGY}

The PRISMA (Preferred Reporting Items for Systematic Review and Meta-Analysis) guidelines have been followed for this systematic review.

\section{Databases and Eligibility Criteria}

Literature was searched electronically on various databases such as PEDro, PubMed Central, Google Scholar, BioMed Central, MEDLINE, EMBASE and Science Direct considering duration of 2011 to 2019. The retrieval strategies were utilized in order to perform article search include keywords, MeSH terms with use of Booleans such as "Visceral Mobilization AND low back pain", "Visceral mobilization AND LBP", "Visceral Mobilization and Manipulation", "VM AND LBP".

\section{Eligibility of Studies}

Randomized Control Trials investigating effectiveness of visceral manipulation or mobilization, either, in the comparison with different modalities or with sham/placebo from 2011 to 2019 were included. The flow of studies is represented in Figure-1.

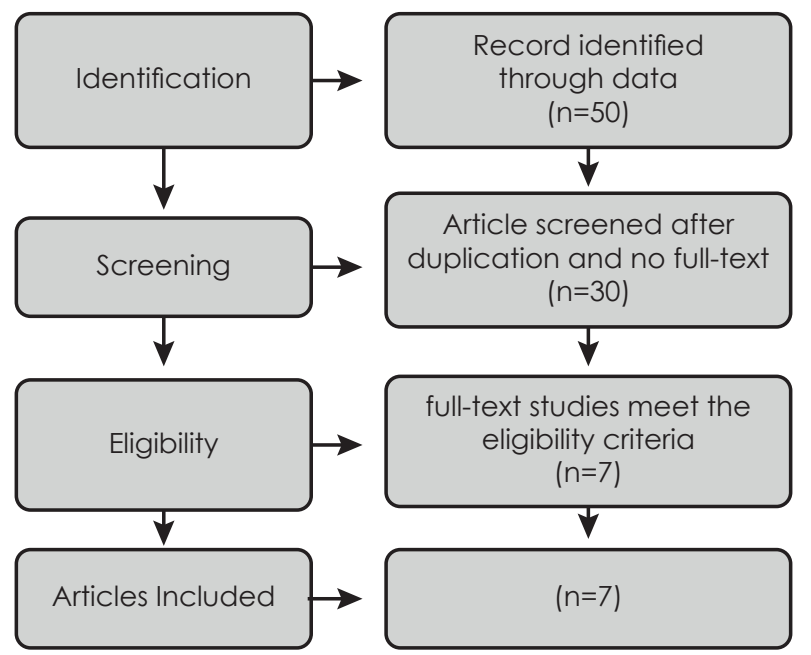

Figure.1 Flow of Studies according to PRISMA 


\section{Study Characteristics}

Among included studies, six were randomized control trials; however one is randomized placebo controlled trial. These studies recruited participants ranging from asymptomatic to those having chronic low back pain and even pregnant females with low back pain. Moreover, six studies compared the effects of visceral mobilization/manipulation with sham or placebo; but one study compared visceral mobilization with a combination of visceral mobilization and an intravaginal treatment maneuver. The characteristics of included researches are demonstrated in the Table-1.

\section{Outcome Measures}

All studies considered perception of pain as the primary outcome measure. Secondary outcome measures consisted of quality of life, functionality, pregnancy mobility index, disability index and ultrasound.

\section{Extraction and Management}

Data was extracted and analyzed according to the inclusion and exclusion criteria. Studies comparing the role of visceral mobilization/ manipulation and other manual therapy modalities on low back pain either in combination of traditional/conventional physical therapy or as the sole treatment strategy were included. Some of the studies were excluded that did not meet the inclusion criteria such as the studies investigating the effects of visceral manipulation of cervical spine or bowel movements. Moreover, outcomes measures of these studies included pain, disability index, mobility while pregnancy and quality of life. Considering the standardized protocols, all data were collected in a structured table in order to maintain the accuracy and validity of data. A standardized table was formulated to categorize the researches on the basis of first author's name, sample size, target population, provided intervention, outcome measures and results of each specific study that is represented as Table-1.

\section{RESULTS}

\section{Selection of Articles}

A total of 50 research articles were retrieved from various databases including such as PEDro, PubMed Central, Google Scholar, BioMed Central, MEDLINE, EMBASE and Science Direct published between the duration of 2011 to 2019. Considering the inclusion criteria, only seven studies were included. Data was extracted and quality assessment was performed using standardized protocol of PRISMA guidelines. However, due to heterogeneity among the selected articles and their outcomes measures meta-analysis could not be performed.

\section{Synthesis of Studies}

All the outcomes measures were assessed for each study with the interventions applied in order to examine the impact of visceral mobilization in improving low back pain as the primary outcome as well as functionality and quality of life. Conclusively, researches including Tamer et al18 and Santosa et all6 demonstrated significant difference in pain among the participant that received Visceral manipulation either in combination or alone with the $p$-value $=0.9$. Panagoloulos et al19 found no significant effect of visceral mobilization in between the group analysis. However, pain levels significantly decreased within both groups after visceral mobilization with or without vaginal maneuvers with $p$-valve $<0.05$. Similar improvement was found for Pregnancy-Mobility Index (PMI) and Oswestry Disability Index. Therefore, this study affirmed the impact of visceral mobilization. Moreover, Panagoloulos et al19 revealed non-significant impact of visceral mobilization in short term i.e. duration of 2 weeks, however, significant impact on 52 weeks. Thus, this advocated the effectiveness of long term application of visceral mobilization in improving low back pain. Furthermore, McSweeney et al. 201220 came up with the significant improvement in low back pain among experimental group that received visceral mobilization specifically mobilization of sigmoid colon. Consecutively, Tozzi et al 21,22 concluded that Manual Fascial Techniques and Osteopathic Manipulation are effective to release area of impaired sliding fascial mobility, and to improve pain perception over a short term duration in people with non-specific low back pain. All the outcomes are represented in Table 2.

\section{Risk of Bias and Overall Study Quality}

Quality of the studies and risk of bias was assessed using Cochrane's standardized checklist and represented as Table-3.

\section{Selection Bias}

\section{Random Sequence Generation}

According to the author's judgment, random Sequence generation of all seven studies $16,17,18,19,20,21,22$ included in the systematic review demonstrated low risk of bias.

\section{Allocation concealment}

Similarly all the included studies $16,17,18,19,20,21,22$ showed low risk of bias with respect to allocation concealment criterion.

\section{Performance Bias}

\section{Blinding of participants and personnel}

Performance bias assessment revealed that Santosa et al16, Panagopoulos et la14 and Mcsweeney20 reported low risk of bias.

However, study of Weisner et all7 showed high risk of bias while a single study Tamer et al 18 provided 
no information regarding blinding of participant and personnel.

\section{Detection Bias}

\section{Blinding of Outcome Assessment}

Three studies 14,16,20 reported low risk of bias. However, one study 17 showed high and one 18 showed unknown risk of bias.

\section{Attrition Bias}

Incomplete Outcome Data

Three out of five studies 14,17,20 reported the loss to follow-up data and incomplete outcome data. However, studies of Tamer et al 18 and Santosa et all6found to commit attrition bias.

\section{Reporting Bias}

\section{Selective Reporting}

All the included studies 16,17,18,19,20,21,22 showed low risk of bias.

Table-1 represents characteristics of included studies $(n=7)$

\begin{tabular}{|c|c|c|c|c|c|c|}
\hline $\begin{array}{l}\text { Author } \\
\text { (Year) }\end{array}$ & $\begin{array}{c}\text { Sample } \\
\text { Size } \\
\text { (n) }\end{array}$ & $\begin{array}{l}\text { Study } \\
\text { Design }\end{array}$ & $\begin{array}{c}\text { Target } \\
\text { Population }\end{array}$ & Intervention & Outcomes & Results \\
\hline $\begin{array}{l}\text { Santos et al } \\
(2019)^{16}\end{array}$ & 20 & $\begin{array}{l}\text { Preliminary, } \\
\text { Randomized, } \\
\text { Controll ed, } \\
\text { Double-Blind } \\
\text { Clinical Trial }\end{array}$ & $\begin{array}{c}\text { Chronic } \\
\text { Low Back } \\
\text { Pain } \\
\text { (Aged 18-80 } \\
\text { years) }\end{array}$ & $\begin{array}{l}\text { Experimental group performed } \\
\text { conventional physical therapy + } \\
\text { visceral mobilization, } 50 \text { mins } \\
\text { session, once/week for } 5 \text { weeks } \\
\text { Control group performed } \\
\text { conventional physical therapy + } \\
\text { placelo visceral mobilization, } \\
50 \text { mins session, once/week for } \\
5 \text { weeks }\end{array}$ & $\begin{array}{l}\text { Pain } \\
\text { Lumber mobility } \\
\text { Functionality }\end{array}$ & $\begin{array}{l}\text { Experimental } \\
\text { group } \\
\text { significantly } \\
\text { improves lumbar } \\
\text { mobility and } \\
\text { (p<0.05), No } \\
\text { significant pain } \\
\text { differences was } \\
\text { observed }\end{array}$ \\
\hline $\begin{array}{l}\text { Wienar et al } \\
(2017)^{17}\end{array}$ & 46 & $\begin{array}{c}\text { Randomized, } \\
\text { Controlled } \\
\text { Trial }\end{array}$ & $\begin{array}{l}\text { Females } \\
\text { with } \\
\text { pregnancy } \\
\text { related low } \\
\text { back pain } \\
\text { (>18 years) }\end{array}$ & $\begin{array}{c}\text { Experimental group received } \\
\text { Visceral Mobilization with } \\
\text { intravaginal treatment, } 3 \\
\text { treatments within } 3 \text { weeks } \\
\text { Control group receives Visceral } \\
\text { Mobilization only, } 3 \text { treatments } \\
\text { within } 3 \text { weeks }\end{array}$ & $\begin{array}{c}\text { VAS } \\
\text { Oswestory } \\
\text { Disability Index } \\
\text { Pregnancy } \\
\text { Mobility Index }\end{array}$ & $\begin{array}{l}\text { Osteopathic } \\
\text { treatments } \\
\text { showed } \\
\text { significant effects } \\
\text { in reducing pain } \\
\text { and increasing } \\
\text { the lumbar range } \\
\text { of motion } \\
(p<0.05)\end{array}$ \\
\hline $\begin{array}{l}\text { Tamer et al } \\
(2017)^{18}\end{array}$ & 39 & $\begin{array}{l}\text { Randomized, } \\
\text { Controlled } \\
\text { Trial }\end{array}$ & $\begin{array}{c}\text { Chronic } \\
\text { non-specific } \\
\text { low back } \\
\text { pain } \\
\text { (Aged }>25 \\
\text { years) }\end{array}$ & $\begin{array}{l}\text { Visceral Osteopathic Method } \\
\text { group received Lymphatic, } \\
\text { Liver Pumping, Pelvic Floor, } \\
\text { Diagphram Relaxation } \\
\text { Technique, Neurovascualr } \\
\text { Technique, Visceral Organ } \\
\text { Fascial Mobilization, } 2 \\
\text { Sessions/Week For } 5 \text { Weeks } \\
\text { Osteopathic Method group } \\
\text { Soft-tissue mobilization, } \\
\text { Muscle Energy Technique, } \\
\text { manipulation and mobilization } \\
\text { for lumber segments, plus } \\
\text { stabilization, strengthening, } \\
\text { stretching Exercise, } 2 \\
\text { sessions/week for } 5 \text { weeks }\end{array}$ & $\begin{array}{c}\text { Pain } \\
\text { Quality of Life }\end{array}$ & $\begin{array}{c}\text { Both } \\
\text { managements } \\
\text { were found to be } \\
\text { effective on pain } \\
\text { and function, } \\
\text { physical function } \\
\text { and Quality of } \\
\text { Life ( } p<0.05 \text { ) }\end{array}$ \\
\hline $\begin{array}{l}\text { Panagopoulos et al } \\
\qquad(2014)^{19}\end{array}$ & 64 & $\begin{array}{c}\text { Randomized, } \\
\text { Placebo } \\
\text { Controlled } \\
\text { Trial }\end{array}$ & $\begin{array}{l}\text { Low Back } \\
\text { Pain } \\
\text { (Aged 18-80 } \\
\text { years) }\end{array}$ & $\begin{array}{l}\text { Standard PT+ real visceral } \\
\text { manipulation, 1-2 times/week } \\
\text { for } 6 \text { weeks } \\
\text { Standard PT+ Sham visceral } \\
\text { manipulation, l-2 times/week } \\
\text { for } 6 \text { weeks }\end{array}$ & $\begin{array}{c}\text { Pain } \\
\text { Functionality } \\
\text { Disability }\end{array}$ & $\begin{array}{l}\text { Visceral } \\
\text { manipulation in } \\
\text { addition to } \\
\text { standard care is } \\
\text { not effective in } \\
\text { changing short } \\
\text { term outcomes }\end{array}$ \\
\hline
\end{tabular}




\begin{tabular}{|c|c|c|c|c|c|c|}
\hline $\begin{array}{l}\text { McSweeney et al } \\
(2012)^{20}\end{array}$ & 15 & $\begin{array}{l}\text { A Single- } \\
\text { Blinded, } \\
\text { Randomized, } \\
\text { Within } \\
\text { Subjects, } \\
\text { Repeated } \\
\text { Measures }\end{array}$ & $\begin{array}{l}\text { Low Back } \\
\quad \text { Pain } \\
\text { (Aged }>18 \\
\text { years) }\end{array}$ & $\begin{array}{c}\text { Experiment conditions } \\
\text { consisted of a visceral } \\
\text { osteopathic } \\
\text { mobilization of the sigmoid } \\
\text { colon, sham intervention of } \\
\text { manual contact on } \\
\text { abdomen, and aon- } \\
\text { intervention group (control) } \\
\\
\text { Each subject received all three } \\
\text { interventions on separate } \\
\text { occasions, with a minimum of } \\
48 \mathrm{~h} \text { between each }\end{array}$ & Pain & $\begin{array}{l}\text { Statistically } \\
\text { significant } \\
\text { improvement in } \\
\text { pressure pain } \\
\text { thresholds } \\
\text { immediately after } \\
\text { the intervention } \\
(P<0.001) \text {. }\end{array}$ \\
\hline $\begin{array}{l}\text { Tozi et al } \\
(2012)^{21}\end{array}$ & 101 & $\begin{array}{c}\text { Randomized } \\
\text { Controlled } \\
\text { Trial }\end{array}$ & $\begin{array}{c}\text { Asymptomat } \\
\text { ic volunteers } \\
\begin{array}{c}\text { (Aged }>18 \\
\text { years }\end{array}\end{array}$ & $\begin{array}{c}\text { Experimental group received } \\
\text { Osteopathic Fascial } \\
\text { Manipulation to the lumbar } \\
\text { region lasting not more than } 31 / 2 \\
\text { min in total } \\
\text { Control group received a sham } \\
\text { treatment by } \\
\text { someone who did not have any } \\
\text { knowledge of anatomy or } \\
\text { experience in manual therapy }\end{array}$ & $\begin{array}{l}\text { Pain } \\
\text { Ultrasound on } \\
\text { Kidney and } \\
\text { Bladder }\end{array}$ & $\begin{array}{l}\text { OFM } \\
\text { Improved kidney } \\
\text { mobility and } \\
\text { reduction of pain } \\
\text { perception over } \\
\text { the short-term }\end{array}$ \\
\hline $\begin{array}{l}\text { Tozi et al } \\
(2011)^{22}\end{array}$ & 60 & $\begin{array}{l}\text { Randomized } \\
\text { Controlled } \\
\text { Trial }\end{array}$ & $\begin{array}{l}\text { Low Back } \\
\text { Pain } \\
\text { (Aged 18-60 } \\
\text { years) }\end{array}$ & $\begin{array}{c}\text { Experimental group received } \\
\text { Manual Facial Techniques on } \\
\text { the painful areas. } \\
\text { Control group blindly received } \\
\text { a sham treatment } \\
\text { by someone who did not have } \\
\text { any knowledge of anatomy or } \\
\text { experience in manualtherapy }\end{array}$ & $\begin{array}{l}\text { Pain } \\
\text { Ultrasound on } \\
\text { Kidney }\end{array}$ & $\begin{array}{l}\text { MFTs are } \\
\text { effective to } \\
\text { release area of } \\
\text { impaired sliding } \\
\text { fascial mobility, } \\
\text { and to improve } \\
\text { pain perception } \\
\text { over a short term } \\
\text { duration }(p<0.05)\end{array}$ \\
\hline
\end{tabular}

\begin{tabular}{|c|c|c|c|c|c|c|}
\hline Studies & 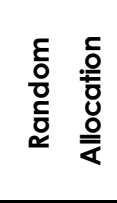 & 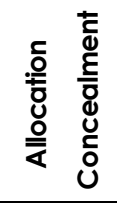 & 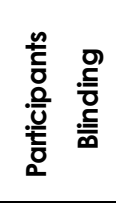 & 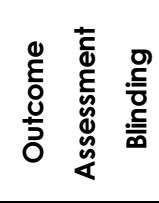 & 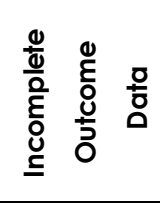 & 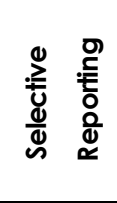 \\
\hline $\begin{array}{l}\text { Santos et al } \\
(2019)^{16}\end{array}$ & $\checkmark$ & $\checkmark$ & $\checkmark$ & $\checkmark$ & $x$ & $\checkmark$ \\
\hline $\begin{array}{c}\text { Wienar et al } \\
(2017)^{17}\end{array}$ & $\checkmark$ & $\sqrt{ }$ & $x$ & $x$ & $\checkmark$ & $\checkmark$ \\
\hline $\begin{array}{c}\text { Tamer et al } \\
(2017)^{18}\end{array}$ & $\checkmark$ & $\checkmark$ & $?$ & $?$ & $x$ & $\checkmark$ \\
\hline $\begin{array}{c}\text { Panagopoulos ef al } \\
(2014)^{19}\end{array}$ & $\checkmark$ & $\checkmark$ & $\checkmark$ & $\checkmark$ & $\checkmark$ & $\checkmark$ \\
\hline $\begin{array}{c}\text { MCSweeney et al } \\
(2012)^{20}\end{array}$ & $\checkmark$ & $\checkmark$ & $\checkmark$ & $x$ & $\checkmark$ & $\checkmark$ \\
\hline $\begin{array}{l}\text { Tozzi et al } \\
(2012)^{21}\end{array}$ & $\sqrt{ }$ & $\checkmark$ & $\checkmark$ & $\checkmark$ & $x$ & $\checkmark$ \\
\hline $\begin{array}{l}\text { Tozzi et al } \\
(2011)^{22}\end{array}$ & $\checkmark$ & $\checkmark$ & $\checkmark$ & $\checkmark$ & $x$ & $\checkmark$ \\
\hline \multicolumn{7}{|c|}{$\begin{array}{l}\mathbf{X}, \text { indicates high risk of bias } \\
\checkmark \text {, indicates low risk of bias } \\
?, \text { indicates that the defined methodology cannot ensure risk of bias. }\end{array}$} \\
\hline
\end{tabular}




\section{DISCUSSION}

The selected all studies were done on effects of visceral mobilization in low back pain. In all articles there were not specified the specific area of the pain in lower back16-22. One study did not mention the complete results of their studies. In some literature low back pain is defined as a symptom characterized by tension and muscle stiffness in the waist region without any pathology, body muscle spasm and normal joint movements 21 . In our study pain intensity was reduced in both OMT and VOMT groups. In placebo controlled, assessors- blinded clinical trial explained the effects of OVM program in 6th week. We believed that visceral applications have a great impact in low back pain patients. Different physiotherapy techniques such as spinal mobilization and fascial releasing techniques have big impact in reducing low back pain23-24. We think, visceral fascial limitation provoking the pain in lumber segment. We concluded from one study that a specific abdominal viscera such as sigmoid colon mobilization reduces the low back pain 12 . We concluded that time and resource restrict the resulted in a small sample size and this may limits the significance of results. Viscera's manipulation has limited hypoalgesic effects in LBP, but this difference could also be demonstrated by the fact that our study fined, visceral manipulation in conjunction with standard care that we used placebo to blind participants to treatment. The outcomes and physical relevance of these studies will be vital, not only for researchers and policy makers, but it's also for patients who suffering from nonspecific low back pain and functional constipation23-25. In some studies therapist will not be blinded which is the limitation. In one study we conclude the results at the end of the sixth week, in which a total of 10 sessions were applied being two sessions per week. Limited number of patients and the lack of long term follow-up in the placebo control group, as well as the instability to give the results with different physiotherapy methods, functional and objective evaluation methods are the limitation of this study. There were no remarkable adverse effects were reported by the participants in any of included study. However, the most common complaint includes discomfort after intervention and no serious adverse effect was reported21.

\section{CONCLUSION}

It was concluded that effects of visceral mobilization in low back pain is significant, provided moderate to high quality evidence upon the effectiveness of visceral manipulation/ mobilization with low to medium risk of bias however the segment was not filtered among the studies.

\section{REFERENCES}

[1] Hartvigsen J, Hancock MJ, Kongsted A, Louw Q, Ferreira ML, Genevay S, Hoy D, Karppinen J, Pransky G, Sieper J, Smeets RJ. What low back pain is and why we need to pay attention. The Lancet. 2018;391 (10137):2356-67.

[2] Hoy D, March L, Brooks P, Blyth F, Woolf A, Bain C, Williams G, Smith E, Vos T, Barendregt J, Murray $C$. The global burden of low back pain: estimates from the Global Burden of Disease 2010 study. Annals of the rheumatic diseases. 2014;73(6):968-74.

[3] Wu A, March L, Zheng X, Huang J, Wang X, Zhao J, Blyth FM, Smith E, Buchbinder R, Hoy D. Global low back pain prevalence and years lived with disability from 1990 to 2017: estimates from the Global Burden of Disease Study 2017. Annals of Translational Medicine. $2020 ; 8(6)$.

[4] Patrick N, Emanski E, Knaub MA. Acute and chronic low back pain. Medical Clinics. 2014 ;98(4):777-89.

[5] Wong AY, Karppinen J, Samartzis D. Low back pain in older adults: risk factors, management options and future directions. Scoliosis and spinal disorders. 2017;12(1):14.

[6] Cruz-Díaz D, Martínez-Amat A, Manuel J, Casuso RA, de Guevara NM, Hita-Contreras F. Effects of a six-week Pilates intervention on balance and fear of falling in women aged over 65 with chronic low-back pain: A randomized controlled trial. Maturitas. 2015;82(4):371-6.

[7] Williams JS, Ng N, Peltzer K, Yawson A, Biritwum $R$, Maximova T, Wu F, Arokiasamy P, Kowal P, Chatterji S. Risk factors and disability associated with low back pain in older adults in low-and middle-income countries. Results from the WHO Study on Global AGEing and Adult Health (SAGE). PLoS One. 2015 10(6):e0127880.

[8] Karran EL, McAuley JH, Traeger AC, Hillier SL, Grabherr L, Russek LN, Moseley GL. Can screening instruments accurately determine poor outcome risk in adults with recent onset low back pain? A systematic review and meta-analysis. BMC medicine. 2017;15(1):13.

[9] Foster NE, Anema JR, Cherkin D, Chou R, Cohen SP, Gross DP, Ferreira PH, Fritz JM, Koes BW, Peul W, Turner JA. Prevention and treatment of low back pain: evidence, challenges, and promising directions. The Lancet. 2018:391 (10137):2368-83.

[10] Ramdas J, Jella V. Prevalence and risk factors of low back pain.2018

[1 1] Wong AY, Karppinen J, Samartzis D. Low back pain in older adults: risk factors, management options and future directions. Scoliosis and spinal disorders. 2017;12(1):14.

[12] Switters JM, Podar S, Perraton L, Machotka Z. Is visceral manipulation beneficial for patients 
with low back pain? A systematic review of the literature. Int J Osteopath Med. 2019;33:16-23.

[13] Zollars JA, Armstrong M, Whisler S, Williamson S. Visceral and neural manipulation in children with cerebral palsy and chronic constipation: five case reports. Explore. 2019;15(1):47-54.

[14] Manchikanti L, Singh V, Falco FJ, Benyamin RM, Hirsch JA. Epidemiology of low back pain in adults. Neuromodulation: Technology at the Neural Interface. 2014;17:3-10.

[15] Childs JD, Fritz JM, Wu SS, Flynn TW, Wainner RS, Robertson EK, Kim FS, George SZ. Implications of early and guideline adherent physical therapy for low back pain on utilization and costs. BMC health services research. 2015;15(1):150.

[16] Santos LV, Córdoba LL, Lopes JB, Oliveira CS, Grecco LA, Andrade AC, Neto HP. Active Visceral Manipulation Associated With Conventional Physiotherapy in People With Chronic Low Back Pain and Visceral Dysfunction: A Preliminary, Randomized, Controlled, Double-Blind Clinical Trial. J Chiropr Med 2019;18(2):79-89.

[17] Wiesner A, Guenther-Borstel J, Liem T, Ciranna-Raab C, Schmidt T. Osteopathic intravaginal treatment in pregnant women with low back pain. In International Urogynecology Journal 2017 (Vol. 28, Pp. S1 15-S1 15). 236 Grays Inn Rd, 6th Floor, London Wclx 8hl, England: Springer London Ltd.

[18] Tamer S, Öz M, Ülger Ö. The effect of visceral osteopathic manual therapy applications on pain, quality of life and function in patients with chronic nonspecific low back pain. Journal of back and musculoskeletal rehabili- tation. $2017 ; 30(3): 419-25$.

[19] Panagopoulos J, Hancock MJ, Ferreira P, Hush $\mathrm{J}$, Petocz P. Does the addition of visceral manipulation alter outcomes for patients with low back pain? A randomized placebo controlled trial. Eur J Pain2015;19(7):899-907.

[20] McSweeney TP, Thomson OP, Johnston R. The immediate effects of sigmoid colon manipulation on pressure pain thresholds in the lumbar spine. Journal of bodywork and movement therapies. 2012;16(4):416-23.

[21] Tozzi $P$, Bongiorno D, Vitturini C. Fascial release effects on patients with non-specific cervical or lumbar pain J Bodyw Mov Ther. $2011 ; 15(4): 405-16$.

[22] Tozzi P, Bongiorno D, Vitturini C. Low back pain and kidney mobility: local osteopathic fascial manipulation decreases pain perception and improves renal mobility. J Bodyw Mov Ther2012; 16(3):381-91.

[23] Fernandes WV, Blanco CR, Politti F, de Cordoba Lanza F, Lucareli PR, Corrêa JC. The effect of a six-week osteopathic visceral manipulation in patients with non-specific chronic low back pain and functional constipation: study protocol for a randomized controlled trial. Trials. 2018;19(1):151.

[24] Degenhardt BF, Johnson JC, Brooks WJ, Norman L. Characterizing adverse events reported immediately after osteopathic manipulative treatment. J Am Osteopath Assoc 2018;118(3):141-9.

[25] Slattengren AH, Nissly T, Blustin J, Bader A, Westfall E. Best uses of osteopathic manipulation J Fam Pract 2017;66(12):743-8. 